\title{
8. Derek Freeman at War
}

\author{
Peter Hempenstall
}

When one thinks of Derek Freeman (1915-2001) at war, World War II does not come automatically to mind. Rather one remembers the long, drawn-out war of attack, counterattack and exhausting attrition that immersed Freeman through the 1980s over Margaret Mead and her Samoan researches. Freeman's campaign to demonstrate the shoddiness of Mead's research and the error in her findings about the nature of adolescent sexual freedom among Samoans stretched from the 1960s to virtually the end of his life in 2001. ${ }^{1}$ This is not the place to rehearse the attacks and vilification that Freeman endured from the North American anthropology establishment, but they seared themselves into his soul. And he fought back relentlessly, on the principle that error could be gradually eliminated when all the evidence was revealed, debated and synthesised.

Derek Freeman was perennially at war with others, and they with him. If it was not over Margaret Mead and the nature of Samoan society it was over his later conversion to what he called an 'interactionist anthropology model', in which anthropologists would learn to absorb the neuroscientists' discoveries about brain functions and their evolution and apply them to the study of behaviour in culture. This would produce a more holistic study of humankind, according to Freeman. But it had him (mis)cast as a crude sociobiologist and ethologist, a follower of Konrad Lorenz, E. O. Wilson and others, and therefore dangerously close to racial theories of human evolution. ${ }^{2}$

War and rumours of war swirled endlessly round Freeman. His tenure as Professor of Anthropology at The Australian National University's Research School of Pacific and Asian Studies was marked by controversies over his acerbic relationship with some of his postgraduate students and with colleagues. His acute intellect and passionate mission to eliminate error led him to adopt a seminar debating style that was intimidating, ruthless and, to many observers, hostile to the conventions of academic discourse. ${ }^{3} \mathrm{He}$ was involved in several

1 See Derek Freeman, Margaret Mead and Samoa: The making and unmaking of an anthropological myth (Cambridge, Mass., 1983); Derek Freeman, The Fatal Hoaxing of Margaret Mead: An historical analysis of her Samoan work (Boulder, Colo., 1999).

2 See Derek Freeman, 'Sociobiology: The "antidiscipline" of anthropology', in Ashley Montagu (ed.), Sociobiology Examined (New York, 1980), pp. 198-219; Derek Freeman, “Choice, Values and the Solution of Human Problems', in John B. Calhoun (ed.), Environment and Population: Problems of adaptation (New York, 1983); Derek Freeman, Dilthey's Dream: Essays on human nature and culture (Canberra, 2001), pp. 63-4.

3 The ghost of Derek Freeman patrols the pages of the book of reminiscences about the Coombs Building at the ANU, where his Department of Anthropology was housed: Brij V. Lal and Allison Ley (eds), The Coombs: A house of memories (Canberra, 2006), pp. 45, 65-6, 75-6, 85, 121, 237; and in John Barnes, Humping My Drum: A memoir (Self-published: <www.lulu.com>, 2008), pp. 270-2, 274, 278, 337-8, 345-58, 363, 425, 432. 
controversial incidents that drew his name and eccentricity to the attention of the wider community. One of these involved his own private 'war' against the donation of an Aztec calendar stone to The Australian National University (ANU) by the Mexican Ambassador in Canberra, which involved lurid stories of blood throwing and assaults. ${ }^{4}$

But even Freeman's death in July 2001 did not lead to an armistice. He continues to excite ill feeling among some colleagues and the war against his name runs on, seemingly unabated, even as this piece is being written. ${ }^{5}$ In March 2008, a new theatre of war was opened in the web pages of the Association for Social Anthropology in Oceania (ASAO). An innocent request on the ASAO Bulletin Board about the whereabouts of Freeman's 1940s ethnographic study of the village of Sa'anapu, which he wrote as a thesis for his Diploma in Anthropology at the University of London, elicited an outpouring of agonised correspondence about Freeman among anthropologists in America, Europe and the Pacific. Many of the mailings retailed rumours and gossip about this larger-than-life figure, even the rumour that Derek had stolen and burnt all library copies of the thesis to prevent anyone investigating his conventional structuralist ideas of the time, which ran counter to his later thinking. Others wondered whether he had ever written a real thesis, for he seemed to hide away any evidence of his earliest forays into Samoan research. In fact, a thread of commonsense ultimately prevailed in the postings: one of his former students confirmed Derek's readiness to lend his thesis to those studying Samoa and the correspondence winkled out its eventual provenance and fate. ${ }^{6}$

But before this 'truce' was reached, the armies of anti-Freemanites repeated allegations that in life Freeman was clearly 'mad' and guilty of bullying, damaging behaviour in his relations with colleagues and students. The irony was that Freeman was in this instance himself a victim of posthumous cyberbullying - a form of warfare that some correspondents were notably uneasy about for it seemed to rival Freeman's own reputation and presented as acts of revenge. 'Derek Freeman is our Other', wrote one contributor. 'He is constructed out of all the things that our mentors should never do'.?

4 This incident can be followed in Freeman's own correspondence with university authorities. His extensive papers are held in the Mandeville Special Collections of the Geisel Library at the University of California, San Diego [hereinafter Freeman UCSD]. See box 150, folders 12-13.

5 The latest of numerous rebuttals of Freeman's attacks on Mead is Paul Shankman, The Trashing of Margaret Mead: Anatomy of an anthropological controversy (Madison, Wis., 2009).

6 The present author edited and annotated Freeman's thesis, presented for the Academic Diploma in Postgraduate Anthropology at the University of London in 1948. Freeman never finished his undergraduate degree at Victoria University College in Wellington in the 1930s and was therefore not allowed to pursue a PhD using his Samoan work. His diploma thesis was published as Derek Freeman, The Social Structure of a Samoan Village Community, Peter Hempenstall (ed.) (Canberra, 2006). Freeman later wrote his PhD thesis on the Iban people of Sarawak, a version of which was published as Iban Agriculture: A report on the shifting cultivation of hill rice by the Iban of Sarawak (London, 1955).

7 Posting, <asaonet@listserv.uci.edu>, 4 March 2008. 
By a roundabout way, World War II did figure in this latest campaign. A story was posted quoting an unnamed informant who remembered talking to Freeman in the 1960s about his presence in Singapore in 1945 when the Japanese surrender was taken. Freeman allegedly remembered an Australian Navy admiral announcing that the sailors could rape and loot, but they must not disturb or destroy any official records. The informant claims this had a profound effect on Freeman, as did the behaviour of Allied sailors on the island.$^{8}$ To explore where Freeman was during World War II, and how war laid the foundations for his later career and feelings, it is necessary to begin in his homeland, New Zealand, and investigate the origins of his various quests.

John Derek Freeman was born in Wellington on 16 August 1916. His Australianborn father was a hairdresser with an elegant salon in the city. Derek's mother, also born in Australia but resident in New Zealand since she was a child, was the daughter of a prominent Presbyterian family. She possessed undoubted influence over the young Derek. She wanted him to be a missionary (which, eventually, in a way, he became). Family members were formidable Christian characters and the house was suffused with a religious atmosphere. A constant tension reigned between his mother, who was accustomed to high culture and good music, and his father, who was no intellectual and simply wished Derek to join him in the business. Their relationship was the crucible in which Freeman's personality was formed-Derek admitting late in life that he was perhaps turned against his father by his mother: the 'good' mother and the 'ineffectual' father who did not understand the higher values and was condescending and negative towards him. ${ }^{9}$ His sister, Margaret, remembered him as strong, argumentative and fearsome in his strength: "you always were going to be a "Great Man".' ${ }^{10}$ Yet Freeman suffered from self-doubt at school over his inability to spell.

He went on to Wellington Technical College - another blow from the wrong side of the street, allegedly because his father refused to pay his fees to university. But he worked to earn the money and in 1934 enrolled at Victoria University College (one of the four colleges within the University of New Zealand) to study psychology, philosophy and education. ${ }^{11}$ The college was small- no more than 700-1000 students during the 1930s — and suffered from the financial sacrifices

8 Posting, <asaonet@listserv.uci.edu>, 5 March 2008.

9 Personal communication, Don Tuzin, 31 August 2006.

10 Margaret Brock to Freeman, 8 August 1992, Freeman UCSD, box 153, folder 5.

11 The material on Freeman's early life, when not separately documented, comes from interviews with Freeman's wife, Monica Freeman, in October and November 2002, December 2003, and December 2005; discussions with Don Tuzin, who before his death in 2007 was working on a biography of Freeman; from Don Tuzin, 'Derek Freeman (1916-2001)', American Anthropologist, 104:3 (2002), pp. 1013-15; and Derek Freeman, 'Notes Towards an Intellectual Biography', which became the opening chapter in G. N. Appell and T. N. Madan (eds), Choice and Morality in Anthropological Perspective: Essays in honour of Derek Freeman (Albany, NY, 1988), pp. 3-27. I have used Freeman's annotated copy of this manuscript chapter, loaned by Mrs Freeman, since it presumably represents his 'authorised' version. 
forced on all educational institutions by the Great Depression. Nonetheless, the 1930s was the beginning of an age of social-science initiatives at Victoria, with modernist trends in educational development filtering through and appointments of young intellectuals in psychology, history, English and education to take over from a tiring professoriate of an older generation. ${ }^{12}$ Two Beagleholes were at the centre of the renaissance: John, as a lecturer in history, later the pre-eminent editor of James Cook's journals and his biographer, and his younger brother, Ernest, in psychology, student of Ginsburg at London and Sapir at Yale and a researcher alongside Peter Buck at the Bishop Museum in Hawai'i. Ernest Beaglehole eventually rose to the Chair of Psychology and produced anthropological studies as well. ${ }^{13}$ Under his teaching, Derek Freeman began to imagine the possibility of doing anthropological fieldwork with a psychological edge somewhere in Polynesia (though there was as yet no formal course in anthropology at Victoria).

The 1930s also of course witnessed the crisis of capitalism in the Depression, alongside the rise of fascism, socialist resistance by communists throughout Europe, and the slide towards world war again. These had their bitter impacts on the college where academic freedom became an issue in the establishment's opposition to socialist and pacifist tendencies. Indeed in 1940, with war broken out, the College Council terminated the appointment of a tutor who had published a pacifist pamphlet, and New Zealand descended into an era of censorship and internment harsher even than Britain's. ${ }^{14}$

Derek Freeman was to fall foul of this approach to war himself (though he was never a Marxist or communist fellow traveller), but as a student in the 1930s he took a full and active part in the life of Victoria College, whose student body was reputed to be the most radical in New Zealand. ${ }^{15}$ He was secretary of the anti-war movement, ran a Free Discussions Club, produced and acted in plays, and was on the editorial staff of the students' annual magazine, Spike, from 1936 and was literary editor then editor of the weekly students' newspaper, Salient, in 1938-39. In 1937 he took out first prize in Spike's literary competition with three poems that were judged 'intricate and difficult', though he showed 'a greater poetic sensibility and a wider range of knowledge and experience than any of the others' ${ }^{16}$ One of his winning poems, '(lovE)ution', suggested a growing disillusionment with New Zealand:

12 Rachel Barrowman, Victoria University of Wellington 1899-1999: A history (Wellington, 1999), pp. 50-75 ('The Hunter Years').

13 Ibid., p. 57.

14 See Jonathan Scott, Harry's Absence: Looking for my father on the mountain (Wellington, 1997); also J. E. Cookson, 'Appeal Boards and Conscientious Objectors', in John Crawford (ed.), Kia Kaha: New Zealand in the Second World War (Auckland, 2002), pp. 173-98.

15 Barrowman, Victoria University of Wellington, p. 53.

16 Spike, 36:65 (1937), p. 49. 
ONCE I would have said-

'There is nothing of confining here

no hemming in

between the deliberate dissonance of walls

naught but the full quick-flowing beauty

of water curving round a stone'.

AND NOW 'Empty-

Empty are the ways of this land,

As empty as a Lord mayor's laugh.

Empty - yes and bitter

— bitter as the unvintageable sea.'

Another poem, 'Bishop', also published in Spike, reveals his distaste for militarism in unambiguous terms:

I watched him stand

By the Military Band

With scroll in hand,

And with syrupy tongue

Sing songs long sung

Of 'heroes young'

(who by some mischance

made excellent dung

for the farmers of France)

Of 'rearming fast,'

And 'things that last,'

And 'all the glories of the past.'

For such as he that stand and vent

The old men's fetid sacrament,

For such as he, and none exempt

The virulence of my contempt. ${ }^{17}$

The same year, he was prominent in a public talk by the German Consul, Dr Hellenthal, at the Free Discussions Club. After a lengthy attempt by Hellenthal to praise the accomplishments of Hitler and the Nazi Party, glossing over questions of rearmament and persecution of the Jews, Freeman and others challenged him to confront the evidence of violence by the Nazi regime. Freeman quoted a British report that documented 447 murders committed by Nazis and wanted to produce photos of people showing injuries from beatings. Hellenthal declared himself insulted and, amid cries for him to justify himself, he walked out. ${ }^{18}$

17 Ibid., p. 30.

18 'Free Discussions Club. Unofficial report on the meeting held on the 8th April 1937' (copy from Mrs Freeman, in author's possession); also Tim Beaglehole, A Life of J. C. Beaglehole: New Zealand scholar (Wellington, 2006), p. 230. 
War was already in the air, and, in 1938, the year of Munich and appeasement, Derek entered the Plunket Medal for Oratory. He did not win the medal but he did win acclaim for his speech on the English poet John Cornford, grandson of Charles Darwin, killed in the Spanish Civil War; Freeman's speech was a semipolitical appeal to the audience to get involved. Spain's agonies more and more provoked Freeman's anger and passion; he won 'best speaker' arguing against Franco's cause in a debate in July $1938 .{ }^{19}$ Freeman much later told his student Don Tuzin that the Spanish Civil War seemed to him the end of civilisation and he resolved to 'get out' of the increasingly tight social and moral atmosphere of New Zealand.$^{20}$ He might also have been moved by a personal tragedy. ClimbingFreeman's favourite pastime - on the flank of Mt Evans in the Southern Alps, he fell with two companions he was roped to: Norman Dowling and Stan Davis. Dowling was killed; Freeman and Davis survived, but Freeman had to carry Davis off the mountain and leave Dowling's body behind. ${ }^{21}$ Freeman's lifelong fascination with mountains was shadowed by this youthful trauma.

The year World War II broke out, Freeman became a disciple of the Indian divine Jiddu Krishnamurti and his radical scepticism about all dogmatisms. Krishnamurti planted in the young student a seed of belief that worldly enlightenment was possible through critical inquiry and 'the primacy of the individual'. ${ }^{22}$ That seed was at odds with the current doctrines of cultural and social anthropology and 'remained a private reserve in his thinking until he began the systematic study of choice in human behaviour' two decades later. ${ }^{23}$ But Krishnamurti released Freeman from many of his earlier passions for politics and engagement and strengthened his questioning.

In 1938, Derek joined Ernest Beaglehole's graduate seminar after studying under Sir Thomas Hunter, the Professor. Hunter was an experimental psychologist but one who taught courses that linked a biological understanding of humans with an appreciation of cultural formation. Beaglehole first interested Freeman in Mead. Both Hunter and Beaglehole had become friends with Margaret Mead and Freeman later admitted he was fed a diet of Mead during these years,

\footnotetext{
19 Salient, 6 July 1938, p. 1.

20 Don Tuzin, Interview with the author, 8 August 2006; also James Belich, Paradise Reforged: A history of the New Zealanders from the 1880s to the year 2000 (Auckland, 2001), pp. 121-5.

21 The full story is in Frank Heiman's recorded interview with Derek Freeman, 12 February 2001, National Library of Australia [hereinafter NLA], Oral History Collection, TRC 4660, pp. 5-7. Freeman's 'Poem for a Friend Killed on Mt. Evans' is in Spike, 37:66 (1938), p. 22. The loss of a climbing companion in the Southern Alps has inspired other creative art in New Zealand - notably, Alistair Campbell's poem 'Elegy', which was set to music by Douglas Lilburn in 1951 as a substantial song cycle for baritone and piano. Alistair Campbell, 'Elegy', Landfall: A New Zealand quarterly, 3:3 (1949), pp. 223-8; Philip Norman, Douglas Lilburn: His life and music (Christchurch, 2006), pp. 175-6. Likewise, Scott's Harry's Absence centres on the death of his father on Mt Cook in 1960.

22 Freeman to David Mackay, 21 November 1997 (letter loaned by Mrs Freeman); Tuzin, ‘Derek Freeman (1916-2001)', p. 5.

23 Appell and Madan, Choice and Morality in Anthropological Perspective, p. 4.
} 
imbibing a general sense of the dominance of culture. In 1938, he wrote for Salient an article entitled 'Anatomy of Mind' in which he declared that the social environment determined the aims and desires that set human behaviour. Freeman remembered standing on a street corner in Wellington watching the flow of humankind, wondering what their behaviour was all about. He accepted that culture was the determinant. ${ }^{24}$ From Beaglehole, Freeman also learned of Freud and psychoanalysis, and carried out some psychological research on the super-ego in young children as a student teacher in several Wellington schools. ${ }^{25}$

Freeman had spent two years training at Wellington Teachers' College when his parents could not, or would not, pay his fees after the first year of university study. ${ }^{26}$ As a student teacher, he proved a gifted guide for small children. One of his former pupils, Heather Morrison, who, as a ten-year-old, encountered Freeman at Ridgeway School in Wellington, remembered how his teaching style was different and emphasised drama, free expression and the making of puppets. He turned 'the worst class in the school' into the best and pointed many students towards later learning. Morrison's memory had lingered for 50 years on the small bag of cherries that Freeman gave each child on the last day of school. ${ }^{27}$

But it was anthropology and the Pacific Islands - specifically Western Samoathat Beaglehole turned Freeman towards as his disillusionment with New Zealand mounted. Here events and influences came together. One of Derek's climbing companions (and fellow activist at Victoria College) was Wolfgang Rosenberg, a young German and a socialist who had left Germany with his wife because of anti-Semitism, had seen the film Moana in Europe, and resolved to get to Samoa from New Zealand, which had obtained the mandate over Western Samoa from the League of Nations. Rosenberg never did get there. But he and Freeman both remembered sitting on Mt Hector in the Tararua Ranges behind Wellington in 1939, with Freeman wondering whether to go to Samoa. Rosenberg encouraged him. ${ }^{28}$ Beaglehole was also promoting Samoa to Derek as a field for study at the same moment the New Zealand Education Department advertised for teachers.

\footnotetext{
24 Heiman's interview, NLA, Oral History Collection, TRC 4660, pp. 5-7, 10.

25 Freeman to Meyer Fortes, 20 September 1962, Freeman UCSD, box 8, folder 9. On Hunter's approach, see Ernest Beaglehole's 1964 Hudson Lecture to the Royal Society of New Zealand, 'The Third Culture in New Zealand: Human nature and conduct', copy in Freeman UCSD, box 118, folder 27; also Freeman to John Money, 13 August 1986, Freeman UCSD, box 15, folder 2, and Kathleen Ross Papers, Alexander Turnbull Library, Wellington, MS-Papers-6963-18. Ross, a playwright, was at Victoria with Freeman.

26 The story that Derek told in old age was that his anti-intellectual father refused to pay his fees and wanted him to get 'real' employment. Freeman tried his hand at a succession of dull jobs before enrolling at Teachers' College, but he kept up his literary and social activities at the university.

27 Heather Packer (née Morrison) to Freeman, n.d. [1998], Freeman UCSD, box 157, folder 32.

28 Freeman to Rosenberg, 7 January 2001, Rosenberg Collection (Copy of letter in author's possession). Wolfgang and Ann Rosenberg, Interview with author, Christchurch, 31 January 2002. Rosenberg became
} 
Western Samoa - a colony of Imperial Germany since 1899-had fallen into New Zealand hands on the outbreak of the Great War. A small naval force had forced the surrender of the German Governor and his officials, and proceeded to install a military regime, which became a civilian administration with the issue of the league's mandate in 1920. New Zealand's administration of the islands was not a happy experience during the inter-war years. Under the Germans, Samoan factions had stirred up political turmoil; a resistance movement based on Savai'i was put down with a mixture of threats and deportations. New Zealand's military regime experienced some economic resistance but it was the flu pandemic of 1919 that caused major resentment - the flu carrying off 20 per cent of the population after a failure in New Zealand quarantine, decimating the ranks of older, experienced chiefs and orators. The 1920s was a period of escalating tension, culminating in a violent confrontation in Apia on 28 December 1929 between marching Samoans and New Zealand police: 11 Samoans and a New Zealand policeman died, among them Samoa's highest-ranking chief, Tupua Tamasese. ${ }^{29}$

By the outbreak of World War II, Western Samoa was much quieter. The Samoan resistance movement, the Mau - both a proto-nationalist movement and one split between churches and major families - had been harassed into sullen, passive resistance, but the election of a Labour government in New Zealand in 1935 brought a new era of reconciliation and some cooperation. War meant a marking of time till peace returned and a new future might be constructed under different conditions.

The New Zealand Education Department had advertised in February 1940 for a male assistant teacher for Leifiifi School in Apia to take the place of a teacher about to join the armed forces overseas. The war was beginning to bite into available staff. The conditions were not particularly inviting. A state education was not compulsory for native Samoans and pupils came and went in a school week of just 16 hours. Class sizes were large - about 70 pupils in each room. Teaching resources, especially materials printed in Samoan, were lacking, libraries were non-existent and the buildings and furniture were poor. ${ }^{30}$ Pastor or mission schools dominated the villages, though the Administration also ran

an economist and academic at Canterbury University. See Gerhard Träbing, 'Wolfgang Rosenberg', in James N. Bade (ed.), Out of the Shadow of War: The German connection with New Zealand in the twentieth century (Melbourne, 1998), pp. 162-8.

29 See Peter Hempenstall and Noel Rutherford, Protest and Dissent in the Colonial Pacific (Suva, 1984), pp. 18-43; Michael Field, Mau: Samoa's struggle for freedom (Auckland, 1991); I. C. Campbell, ‘Resistance and Colonial Government: A comparative study of Samoa', Journal of Pacific History, 40:1 (2005), pp. 45-69.

30 These details are taken from a report, Education in Samoa, written after the war, based on a visit to Samoa by the Director of Education in New Zealand, C. E. Beeby, in June 1945 to report on the state of affairs that prevailed during the war. See Beeby to Secretary External Affairs, 18 July 1947, IT1, EX13/1 Part 2: Education: Samoa General File, 1926-49, Archives New Zealand [hereinafter ArchivesNZ]; C. E. Beeby, The Biography of an Idea: Beeby on education (Wellington, 1992), pp. 212-18. 
village schools staffed by Samoan teachers. Leifiifi was the government school in Apia, with 600 pupils, attended mainly by part-Samoan, part-European children. Most staff were also of mixed descent, though the senior staff were New Zealanders. The salary structure was poorer than in New Zealand and housing was not provided, though a 'tropical allowance' was included.

It was into this atmosphere - of a rather ramshackle New Zealand colonialism seeking an accommodation with a Polynesian people similar to, yet unlike 'their' Maori - that Derek Freeman arrived onboard a banana boat, the Maui Pomare, in April 1940. White prestige and distance from the 'natives' were still the gold standard among civil servants. Samoans were still largely dispersed among their myriad villages strung along the coasts of both Upolu and Savai'i, practising their social and political arts, hardly touched by New Zealand's policies, or the war, the further from Apia one lived.

Freeman had left New Zealand without finishing his degree ${ }^{31}$ but with good references from the Education Department. The Inspector for Schools described him as a young man with 'any amount of ideas, very thoughtful and intelligent, with a great capacity for work and [he] has no difficulty in maintaining discipline' ${ }^{32}$ He was appointed an Assistant Master at Leifiifi School.

In later life, as the nemesis of Margaret Mead and the North American anthropological establishment, Freeman's sense of his time in wartime Samoa was that it was the beginning of his own war against Meadian error. But there is no evidence of a sudden epiphany - more of a drawn-out and cumulative process. Rather like Robert Louis Stevenson and Rupert Brooke, Freeman found Samoa's lushness, its handsome people and the romance of the islands' past arresting and galvanising. The relaxed teaching regime from 8 am till midday afforded him plenty of time to pursue his own interests. He quickly picked up Samoan, studied it formally and sat the Government exam to prove his proficiency; it added a welcome $£ 25$ a year to his salary.

He also began archaeological explorations of caves and earth mounds that he was told about inland from the northern and southern coasts of Upolu. He took precise measurements of the Falemaunga caves $8 \mathrm{~km}$ inland from Malie on the north coast and researched the history of their finding by German planters. On one occasion in 1943, Freeman took 17 Samoans from the Teachers' Training School to clear the site around a large megalithic circle of stone columns, which

\footnotetext{
31 And his grades were not particularly good in the subjects he did complete - achieving only a third class for logic and ethics. See Doug Munro, The Ivory Tower and Beyond: Participant historians of the Pacific (Newcastle upon Tyne, 2009), p. 83. Freeman spent too much time on student activities. For example, the Dramatic Club staged The Royal Inn and Freeman, 'as the American sailor, gave a splendid performance, keeping in character throughout in a perfectly natural manner'. Salient, 29 June 1938, p. 1.

32 Memo for Secretary of External Affairs from Permanent Head Education Dept, n.d., IT1, EX89/3, Part 3, ArchivesNZ.
} 
John Macmillan Brown had in earlier days likened to Stonehenge and which Samoans rumoured was of godly origin. Freeman searched for grave sites, collected traditions and read all the authorities he could find on Samoan myths, from Percy Smith through Augustin Krämer to Margaret Mead. He concluded that Peter Buck was correct that the blocks were natural and the site manipulated through history by the Samoans. Freeman collected all the traditions he could from local talking chiefs (tulafale) and sacred chiefs (ali'i) and wrote up his findings for a series of articles - his first major academic pieces - for the Journal of the Polynesian Society back in New Zealand. ${ }^{33}$ In breaking with older European opinions about the origins of these sites and exploring with Samoans themselves the meaning of traditions surrounding them, Freeman began his oppositional stance on things Samoan - a position he later saw as the start of his 'heretic' reputation. ${ }^{34}$

It was the exploration of Seuao Cave in Safata on the south coast, where he found his first stone adze, that led Freeman to the village of Sa'anapu. ${ }^{35}$ The village lay on a small isthmus facing the sea and to get there one had to walk or ride for more than four hours across Upolu from the administrative centre, Apia, climbing to more than $900 \mathrm{~m}$ before dropping down to the coast. Sa'anapu became his home for the remainder of Freeman's investigations of Samoan culture and the centre of his emotional relations with Samoans. This is where Freeman claimed he began to see through Margaret Mead. ${ }^{36}$ He had probably read Mead under Beaglehole's tutelage in Wellington and he sent away for her Coming of Age in Samoa, which arrived along with her Growing Up in New Guinea and Sex and Temperament in Three Primitive Societies.

Freeman became friendly during his visits to the Seauo Cave with a senior talking chief and village mayor, Lauvi Vainu'u. Having decided to make Sa'anapu his base for detailed ethnographic research alongside his teaching tasks, Freeman discovered that Lauvi regarded him as reparation for the death of his youngest son, Fa' imoto, also known as Loani, or John. John Derek Freeman now became the adopted son of Lauvi Vainu' $\mathrm{u}$ - a privileged position that granted him intimate access to the family circle. His good fortune increased when the assembled chiefs conferred on him the title of Logona-i-taga ('heard at the tree felling') - a title belonging to the manaia or son of the leading chief of the lineage 'Anapu, and thus the leader of the young men of the village. This enabled Freeman to attend

33 'The Falemaunga Caves', Journal of the Polynesian Society [hereinafter JPS], 53:3 (1944), pp. 86-104; 'O le Fele o le Fe'e', JPS, 53:4 (1944), pp. 121-44; 'The Vailele Earthmounds', JPS, 53:4 (1944), pp. 145-62.

34 Heiman's interview, NLA, Oral History Collection, TRC 4660, 14. Freeman was partly projecting back in the shadow of David Williamson's play about him and Margaret Mead: Heretic: Based on the life of Derek Freeman (Melbourne, 1996).

35 'The Seuao Cave', JPS, 52:3 (1943), pp. 101-9.

36 Freeman, Margaret Mead and Samoa, pp. xiii-xiv. 
all fono, or village councils, and, with his fluent Samoan, to understand their oratory and observe at first hand the behaviour of chiefs from the perspective of the young men. ${ }^{37}$

Freeman's notes from 1942-43 document his meticulous approach as an ethnographer. He observed the daily routine of his family and listed their comings and goings, and their periods of rest and sleep. He collected instances of the intrigues of the matai (title-holders) who made up the village council, noting how disputes were not allowed to be referred beyond village boundaries to the Administration, even though this was illegal. Neat plans of the village square (malae) were filed, along with seating arrangements at fono, lists of matai titles and their holders, and kinship charts. He researched the history of Sa'anapu during the conflicts of the nineteenth century that preceded the annexation of Western Samoa to Germany and discovered the village was split between followers of Tamasese and the eventual victor as paramount titleholder, Mata'afa Iosefo. He began to recognise the fluidity in Samoan cultural behaviour, the series of precedents and rights and gracious deferrals that qualified the ideal seating arrangements and speaking rights among matai. His stories about ghosts, or aitu, which were treated carefully by Samoans, and the religious implications for current religious practices, became a seminar paper to colleagues at the London School of Economics (LSE) after the war. ${ }^{38}$ Freeman was also capable of a poetic, sensual feel for his surroundings and beautiful line drawings of the village and its equipment. He might have been an amateur academic-in-training at this stage in wartime Samoa, but his methods sowed the seeds of his later reputation as a superior ethnographer.

Freeman spent some five months living and working in Sa'anapu during 194243, but he had to maintain his work as a teacher and continued to visit the area on weekends from Apia; Sa'anapu people also visited him in town, the chiefs sometimes staying as his guests. In all Freeman had the village and its surroundings under fairly close scrutiny for 19 months. ${ }^{39}$ He was now living in the lavish home of an Austrian doctor, a refugee from Nazi Germany, Hans Neumann, opposite the hospital. Freeman became very friendly with a Samoan nurse, Sisi, after a fall from his horse. Though it became a passionate, serious affair, Sisi would not allow sexual intercourse for she informed Derek that Samoan culture required her to guard her virginity until after marriage. Freeman later argued this revelation, which he checked with other nurses, along with his

37 Information supplied to the author by Serge Tcherkezoff, January 2006, from his own correspondence with Freeman. The account of Freeman's activities in Sa'anapu is based largely on Heiman's interview, NLA, Oral History Collection, TRC 4660, 14-18; and Freeman's own ethnographic notes in his papers: Freeman, UCSD, box 50 .

38 See Peter Hempenstall, "“On Missionaries and Cultural Change in Samoa": Derek Freeman preparing for a "heretical" life', Journal of Pacific History, 39:2 (2004), pp. 241-50.

39 Details in Freeman's December 1946 seminar paper at LSE: 'On Samoan Social Organization' (in possession of the Freeman family). 
experience in Sa'anapu of witnessing an ifoga, or ceremonial abasement by a matai on account of a rape of a fifteen-year-old girl by a youth, and other similar incidents, persuaded him that Mead had Samoan adolescent sexual behaviour totally wrong. ${ }^{40}$ This is difficult to prove, but Freeman's much more intensive relationship with Samoan culture was certainly moving him to be more sceptical of Mead's picture of a society of free love.

Though Freeman received assistance in his quests from a variety of other Europeans stationed in Samoa, his relations with the Administration turned sour soon after his arrival. On the eve of the Japanese entry into the war, the Acting Administrator in Samoa, A. C. Turnbull, argued to Wellington that Freeman should be sent home for he would not assist the war effort by joining the local defence force or volunteering for overseas service: 'he is a man of peculiar ideas (and undoubtedly a pacifist).' ${ }^{41}$ Pacifism is perhaps too simple a term for the complex of feelings Derek Freeman was carrying. Anti-war sentiments had been part of the education of the children of the Great War-Freeman's generation. It seeped down into school textbooks and journals. By the early 1930s, it had become almost conventional to speak sceptically of modern warfare and its toll on lives and ideals. A religiously inspired pacifism was undoubtedly part of the mix but it was not the only case for resisting state pressures on men to march again to war. Freeman's anti-militarism was partly driven by the kind of disillusionment manifested in the anti-war novels of the 1920s and 1930s, refined by his experiences at university and his contact with Krishnamurti's views. Once war broke out, uncertainty over war aims and the terms of any postwar peace led to opposition to war in all its forms in New Zealand. ${ }^{42}$

Freeman had deliberately escaped the confines of New Zealand's highly regulated society, which endured even greater constraints on freedom of expression and communication once wartime censorship regulations were introduced. New Zealand was the earliest country in the Empire outside Britain to reintroduce conscription. Conscientious objectors to war were brought before Appeals Boards dotted around the country, which determined the genuineness of their cases, without further appeal, and condemned those who refused to accept their decisions to defaulters' concentration camps for the duration of the war. ${ }^{43}$

\footnotetext{
40 Heiman's interview, NLA, Oral History Collection, TRC 4660, 18. Also Don Tuzin, Interview with Freeman, 25-30 June 2000, set IV, 23-32 (in possession of Tuzin family); Tcherkezoff, Information to author, January 2006.

41 Turnbull to Secretary External Affairs, 2 October 1941, IT1, EX89/3, Part 4, ArchivesNZ.

42 For a detailed examination of this aspect of New Zealand history, see F. L. W. Wood, The New Zealand People at War: Political and external affairs (Wellington, 1958), especially pp. 25-7, 111; also Cookson, 'Appeal Boards and Conscientious Objectors', p. 181.

43 Cookson, 'Appeal Boards and Conscientious Objectors', pp. 173-98; Wood, The New Zealand People at War, pp. 123-50; also Srinjoy Bose, 'Students or Soldiers? Conscientious objection during World War II', in The Time Keepers (eds), Tower Turmoil: Characters and controversies at the University of Otago (Dunedin, 2005), pp. 81-94.
} 
Derek Freeman's opposition to war sprang from his frustration with the decay and breakdown of international order and his wish to be free of it all. It saw him ostracised by the expatriate community in Samoa - reinforced by his difference from ordinary Kiwis, his academic pursuits and his open fraternisation with Samoans in their villages. ${ }^{44}$ But the Japanese attack on Pearl Harbor and the dire implications for the defence of New Zealand and the islands to her north brought Freeman up short. Since 1938 the New Zealand Labour Government had been aware that they were to all intents and purposes on their own for an indefinite period if Japan attacked the United States or South-East Asia and Britain was caught in a European conflict. At the Pacific Defence Conference in Wellington, in April 1939, New Zealand took the lead in agreeing to defend Fiji against Japanese aggression but leaving other islands in the South-West Pacific, including Samoa, to be defended by local militia. With the Pearl Harbor attack, conscription was also extended into civilian life and industry. ${ }^{45}$

Freeman joined the local defence force and began patrolling the islands, reaching parts of the group he had never visited. His term as a teacher was due to expire on 9 April 1943, and Freeman initially indicated he was prepared to stay for a further term with the Education Department. ${ }^{46}$ But in November 1943, on furlough, he decided to return to New Zealand and join the Navy. Freeman was a keen yachtsman and had been secretary of the local sailing club in Samoa. He volunteered for Scheme B, a scheme for ratings of the Royal New Zealand Naval Volunteer Reserve who had the potential to become officers after training in Britain; under the Naval Defence Act of 1913, New Zealand warships passed to the control of the British Admiralty in wartime. Some 1100 Scheme B personnel were sent overseas. ${ }^{47}$

Freeman sailed from Wellington for England on a battered tramp steamer, the Themistocles, in company with other aspiring ratings, among whom was Keith Sinclair, the later enfant terrible of New Zealand letters, nationalist poet, commentator and academic historian. ${ }^{48}$ Before he left, Freeman visited Ernest Beaglehole and told him he thought Mead had been in error over her Samoan conclusions; Beaglehole 'sort of just laughed'. ${ }^{49}$ If this was a declaration of hostilities on Freeman's part then it would have to wait, for a larger and more existential war claimed his attention for the next two years.

44 Freeman to Michael Field, 22 November 1984, Freeman UCSD, box 8, folder 1. Jim Davidson encountered the same problems with expatriates in Samoa in the late 1940s and early 1950s. See Doug Munro, 'J. W. Davidson-The making of a participant historian', in Brij V. Lal and Peter Hempenstall (eds), Pacific Lives, Pacific Places: Bursting boundaries in Pacific history (Canberra, 2001), pp. 107-8.

45 Wood, The New Zealand People at War, pp. 67-89, 215.

46 D. McCulloch (Secretary Administration) to Secretary External Affairs, 31 August 1942, IT1, EX89/3, Part 4, ArchivesNZ.

47 Peter Dennerley, 'The Royal New Zealand Navy', in Crawford, Kia Kaha, pp. 110-11.

48 The following account of Freeman's time overseas is taken largely from Sinclair's robust autobiography:

Halfway Round the Harbour: An autobiography (Auckland, 1993), ch. 6 ('To See the World').

49 Heiman's interview, NLA, Oral History Collection, TRC 4660, 19. 
They sailed west to Europe via Australia, the Indian Ocean and South Africa. In Melbourne, both Freeman and Sinclair headed for the Melbourne University Library-Freeman to follow-up translations of Samoan songs, Sinclair to read for exams he still had to sit for his degree. Sinclair's retrospective views on Freeman, who was older than the men he sailed with, present an eccentric figure from the beginning: 'a big man, with a big voice. He was an intellectual extremist or fanatic. ${ }^{50}$ (Freeman later disputed Sinclair's description of him as a 'fanatic' —'a heretic, yes' — but agreed his work against the Meadites might have him accurately described as an intellectual extremist. $)^{51}$ After a stopover in a very hot Perth, the Themistocles limped across the Indian Ocean to Durban, keeping well to the south to avoid Japanese submarines. They spent a month in South Africa observing at close quarters the tightening tentacles of the embryonic apartheid state. One night Freeman stole a South African flag with other sailors and slept on the flag in a gutter. It was a rare instance of high jinks by someone less socially adventurous than Keith Sinclair. The two of themwith their intellectual pursuits and un-nautical appearance - were unlike most of the ratings they trained with.

Once in England from September 1944, their time was taken up with courses of training in signals, weapons, officer leadership, navigation and sailing. There were personality tests, in one of which they had to write about themselves from the standpoint of a severe critic. Freeman recognised in himself the stern disciplinarian (Keith Sinclair admitted he talked too much). But he was emotional and passionate, too. While he was drilling on the parade ground at HMS Raleigh, near Plymouth, in 1945, he received mail informing him that his Samoan lover, Sisi, had died of yellow fever. He wept unashamedly. ${ }^{52}$ They were constantly interviewed by boards and sat exams. Freeman and Sinclair stood out for their unusual verbal and literary skills but were weak at mechanical tests. Nevertheless, at the end of the classes, the drilling, the training on small ships and the induction into rigid Royal Navy behaviour, Freeman placed third and Sinclair fourth and they were commissioned as temporary sublieutenants. Many sailors fell by the wayside; only 11 of 50 Kiwis - four from their draftpassed, with a handful of Englishmen. ${ }^{53}$

The war against the Axis powers was only one of Derek Freeman's campaigns while he was in England. The other was to set up networks and make contacts with scholars in anthropology against the day when the war was over and he could think about a different kind of professional training. The trainee officers had ample leave during their courses and London was the obvious centre for

50 Sinclair, Halfway Round the Harbour, p. 85

51 Freeman to Sinclair, 15 October 1993, Freeman UCSD, box 21, folder 9.

52 Tuzin, Interview with Freeman, Tuzin family, set V, 29.

53 Sinclair, Halfway Round the Harbour, p. 100. 
their attention, though the city was still being targeted by German V1 and V2 rockets. Freeman used the time to approach Raymond Firth, himself a Kiwi and the successor to Malinowski as Professor at the LSE within the University of London. Freeman sent Firth testimonials about his studies in both New Zealand and Samoa. It appears that he hoped to be allowed to register for a $\mathrm{PhD}$ under Firth. Firth encouraged him, setting his sights on Freeman working in either the Gilbert and Ellice Islands or the Solomons after the war. Firth put a case to the Higher Degree Committee and approached the Rehabilitation Board in New Zealand on Freeman's behalf. In May 1945, as the European war was ending, they hit a snag. The University of London regulations would not allow a student to register for a PhD who had not completed his Bachelor's degree; Freeman was one unit shy. The university would not budge, despite Firth's willingness to take Freeman on, given the research work he had already carried out in Samoa. The confusion seems to have been Firth's fault, but compensation came in the form of a favourable decision by New Zealand's Rehabilitation Board to support Freeman to study in London for a Postgraduate Academic Diploma. ${ }^{54}$

These matters were literally academic while the war ground on. After graduation as an officer, Freeman applied to Naval Intelligence and was sent to study Japanese at the School of Oriental and African Studies as a prelude to the postwar occupation. Keith Sinclair later claimed Freeman had gone over the heads of his superior officers to persuade Naval Intelligence he was a linguist, and was subsequently taken off the course and posted to a dangerous assignment in the Far East. ${ }^{55}$ The sequence of events was both more pedestrian and typically Freemanesque. He became impatient at the prospect of months spent studying a new language and approached the Professor of Japanese, a New Zealander, successfully persuading her that he was unsuited to the course, which she duly reported to the Navy. Freeman was assigned to a far more hazardous undertaking: watch officer onboard a landing ship tank (LST) joining the Eastern Fleet - later the British Pacific Fleet - to participate in the last stages of the advance against Japan. ${ }^{56}$

He never reached Japan, or even the Malayan Peninsula that was the invasion target for his LST 9 and crew. When the atomic bomb was dropped on Hiroshima, Freeman and his crew were preparing in Trincomalee Harbour, Ceylon (now Sri Lanka). They were dispatched instead to Hong Kong and thence to the coast of Borneo to take the Japanese surrender. Travelling up and down the coast, Freeman apparently accumulated an impressive collection of Japanese

\footnotetext{
54 This set of circumstances can be traced in Firth's correspondence in Freeman's papers: Firth to Freeman, 22 February 1945, 28 May 1945, 1 July 1946; and Dean Postgraduate Studies to Firth, 11 April 1945, Freeman UCSD, box 8 , folder 4 .

55 Sinclair, Halfway Round the Harbour, p. 86.

56 See Freeman to Sinclair, 15 October 1993, Freeman UCSD, box 21, folder 9; also Dennerley, 'The Royal New Zealand Navy', pp. 118-20.
} 
officers' swords, and, more significantly, had his first encounter with the Iban, an imperious proto-Malay people-headhunters - who lived in large family groups in riverside long houses. Freeman remembered his first sight of them:

When I was on this LST we were beached at the mouth of a river and these Iban tribesmen came swaggering on. They wear little loincloths and had long hair and spears in their hands and they walked straight into the captain's cabin, you know, as if they owned the place. I was enormously impressed by these people, the first really wild people I had seen..$^{57}$

War's end saw his ship carrying troops back to Australia (this is possibly the point at which the story about his presence in Singapore, and shock at the instructions of an admiral to his men, originated). In Brisbane, Derek was put into the tropical diseases hospital, for his skin had erupted into sores that required treatment; it was later determined he was allergic to the anti-malarial drug Atebrin. In Sydney while convalescing, Freeman took the opportunity to refresh and enhance his historical research on Samoa in preparation for further postwar studies. He examined early missionary records in the Mitchell Library and did the same when he reached the Turnbull Library in Wellington. Keith Sinclair bumped into him there as he collected material for his Masters thesis on the Aborigines' Protection Society and New Zealand. ${ }^{58}$ In 1946, Freeman returned briefly to Western Samoa as research assistant for the Irish writer Robert Gibbings, but he already perceived himself as a 'kind of an academic'59 and, by 1947, he was back in London on his rehabilitation bursary, enrolled with Firth to study anthropology.

The rest of Freeman's postwar career is a different history, resonant with controversies, not all of them about Margaret Mead and her anthropology. But Freeman did submit successfully in 1948 his diploma thesis, 'The Social Structure of a Samoan Village Community', on Sa'anapu, which was Freeman's main ethnographic contribution to Pacific studies - a conventional structuralist analysis, but one brimming with the dynamism, fluidity and flexible adaptations engineered by Samoans in their everyday lives. ${ }^{60}$ He went on to do fieldwork with his new wife, Monica, as partner and assistant among the Iban of Borneo between 1949 and 1951, as a project under Edmund Leach's sponsorship with the Colonial Social Science Research Council. On their return to London,

\footnotetext{
57 Heiman's interview, NLA, Oral History Collection, TRC 4660, 24.

58 Sinclair, Halfway Round the Harbour, p. 114.

59 Heiman's interview, NLA, Oral History Collection, TRC 4660, 24. The last stages of Freeman's wartime experiences and the immediate years thereafter are covered here (pp. 24-8).

60 See author's introduction to Freeman's The Social Structure of a Samoan Village Community, pp. 9-13.
} 
Freeman joined Meyer Fortes at Cambridge to write up his materials for his PhD. He was awarded the degree in 1953 and sallied forth on a distinguished, albeit sometimes noisy and acrimonious, academic career.

Derek Freeman's presence in wartime Samoa was not the beginning of his war with Margaret Mead. At best, his stay was part of his own 'phoney' war of gradual revelation and training before the real conflict was joined from the 1960s onwards. His tussles during the 1940s were with the New Zealand colonial establishment and they had nothing to do with the classic suspicion of activist anthropologists by colonial governments. ${ }^{61}$ Rather they were over his standing out from the conventional expectations of a colonial public servant and his initial refusal to join the war effort. Freeman's real war was with himself over his duty of citizenship in a world gone mad and of which he deeply disapproved. In the event, he met and resolved these tensions in favour of fighting for his country and joining the naval arm of the forces arrayed against the Japanese. Though he served in the Royal Navy, he did so as a Kiwi, and he remained a Kiwi till his dying days. Living most of his life in Canberra, Australia, he planted his and Monica's garden with typical New Zealand shrubs and trees. They visited New Zealand several times and Freeman continued to correspond with relatives there. On his coffin at the memorial service after his death in 2001 lay his ice axe - an expression of his abiding love for New Zealand's mountains.

The axe was also a symbol for the rough violence needed to conquer ideas and people in error as well as mountains. It is possible to see World War II as part of the evolutionary curve in Derek Freeman's own formation as a crusader in the moral pursuit of the truth he came to believe it was the duty of scholars to aim for. Questions still hang heavily around the humaneness and the hypocrisies of his methods in prosecuting error and banishing it from scholarship. Perhaps that is why almost no room was found for Freeman in the written history of the ANU. ${ }^{62}$

Freeman's contribution to anthropology is also still in dispute. His considerable work on the Iban is often swamped in estimation by the tidal wave of clamour and dissent over his Samoan 'war' with Margaret Mead's followers. This is not the place to follow that campaign. Samoa remained special in Freeman's life. In 1983, the year his book about Margaret Mead came out, he told his old friend Wolf Rosenberg that he was making arrangements to have his ashes scattered on the south coast of Upolu - 'a place that I have loved like I used to love the Tararuas and the Southern Alps, for over 40 years' ${ }^{63}$

61 Such as bedevilled Ralph Piddington on the Aboriginal frontier in Australia. See Geoffrey Gray, $A$ Cautious Silence: The politics of Australian anthropology (Canberra, 2007), pp. 102-8.

62 See S. G. Foster and Margaret M. Varghese, The Making of The Australian National University, 1946-1996 (Sydney, 1996), p. 110; also correspondence between Freeman and Foster, Freeman UCSD, box 154, folder 29.

63 Freeman to Rosenberg, 15 August 1983, Freeman UCSD, box 19, folder 11. 
